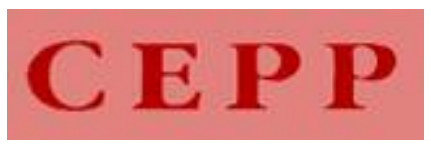

\title{
ROLE OF THE BRAIN PROSTANOIDS IN GLUCAGON-LIKE PEPTIDE-1- INDUCED CENTRAL ACTIVATION OF SYMPATHO-ADRENOMEDULLARY OUTFLOW IN RATS
}

\begin{tabular}{|c|c|}
\hline Journal: & Clinical and Experimental Pharmacology and Physiology \\
\hline Manuscript ID: & CEPP-07-0239.R2 \\
\hline Manuscript Type: & Original Article - Neurobiology \\
\hline $\begin{array}{r}\text { Date Submitted by the } \\
\text { Author: }\end{array}$ & $\mathrm{n} / \mathrm{a}$ \\
\hline Complete List of Authors: & $\begin{array}{l}\text { Arai, Junichi; Kochi University, Pharmacology; Kochi University, } \\
\text { Pediatrics } \\
\text { Okada, Shoshiro; Kochi University, Pharmacology } \\
\text { Yamaguchi-Shima, Naoko; Kochi University, Pharmacology } \\
\text { Shimizu, Takahiro; Kochi University, Pharmacology } \\
\text { Sasaki, Tsuyoshi; Kochi University, Pharmacology; Kochi University, } \\
\text { Pediatrics } \\
\text { Yorimitsu, Mieko; Kochi University, Pharmacology } \\
\text { Wakiguchi, Hiroshi; Kochi University, Pediatrics } \\
\text { Yokotani, Kunihiko; Kochi University, Pharmacology }\end{array}$ \\
\hline Keywords: & $\begin{array}{l}\text { glucagon-like peptide- } 1 \text {, plasma catecholamine, sympatho- } \\
\text { adrenomedullary system, thromboxane A2, Cyclooxygenase }\end{array}$ \\
\hline
\end{tabular}




\title{
ROLE OF THE BRAIN PROSTANOIDS IN GLUCAGON-LIKE PEPTIDE-1-INDUCED CENTRAL ACTIVATION OF SYMPATHO-ADRENOMEDULLARY OUTFLOW IN RATS
}

\author{
Junichi Arai $^{\mathrm{H}, \dagger}$, Shoshiro Okada ${ }^{\mathrm{H}}$, Naoko Yamaguchi-shima ${ }^{\mathrm{H}}$, Takahiro \\ Shimizu $^{\mathrm{H}}$, Tsuyoshi Sasaki ${ }^{\mathrm{H}, \dagger}$, Mieko Yorimitsu ${ }^{\mathrm{H}}$, Hiroshi Wakiguchi ${ }^{\dagger}$, \\ Kunihiko Yokotani ${ }^{\mathrm{H}}$ \\ ${ }^{H}$ Department of Pharmacology and ${ }^{\dagger}$ Department of Pediatrics, Graduate School of \\ Medicine, Kochi University, Nankoku, Kochi 783-8505, Japan \\ Short title: GLP-1 and sympatho-adrenomedullary outflow
}

\begin{abstract}
Correspondence: Dr. Shoshiro Okada, Department of Pharmacology, Graduate School of Medicine, Kochi University, Nankoku, Kochi 783-8505, Japan.

Phone and FAX: +81-88-880-2328

Email: okada@kochi-u.ac.jp
\end{abstract}




\section{SUMMARY}

1. The aim of the present study was to characterize the source of plasma catecholamines induced by centrally administered glucagon-like peptide-1 (GLP-1), with regard to the brain prostanoids, in urethane-anesthetized rats.

2. GLP-1 and other compounds were administered intracerebroventricularly (i.c.v.), and blood samples were collected via a cannula inserted into the femoral artery. Catecholamines were extracted from plasma with activated alumina and were assayed electrochemically with high-performance liquid chromatography.

3. GLP-1 (0.3, 1.0 and $3.0 \mathrm{nmol} / \mathrm{animal})$ dose-dependently elevated plasma levels of noradrenaline and adrenaline, and GLP-1 (1.0 nmol)-induced response was reduced by exendin (5-39) (a selective GLP-1 receptor antagonist) in a dose-dependent manner (5 and $10 \mathrm{nmol} /$ animal). The GLP-1-induced elevation of both catecholamines was abolished by indomethacin (an inhibitor of cyclooxygenase ) $(1.2 \mu \mathrm{mol} / \mathrm{animal})$, while baicalein (a lipoxygenases inhibitor) $(1.2 \mu \mathrm{mol} / \mathrm{animal})$ had no effect.

4. Furegrelate (an inhibitor of thromboxane $\mathrm{A}_{2}$ synthase) $(1.8 \mu \mathrm{mol} / \mathrm{animal})$ and (+) $\mathrm{S}-145$ (a thromboxane $\mathrm{A}_{2}$ receptor antagonist) (625 nmol/animal) attenuated the GLP-1-induced elevation of plasma adrenaline, but these reagents had no effect on the elevation of plasma noradrenaline. The GLP-1-induced elevation of plasma adrenaline was abolished by acute bilateral adrenalectomy, but the procedure had no effect on the elevation of plasma noradrenaline.

5. These results suggest that centrally administered GLP-1 induces the secretion of adrenaline from the adrenal medulla by brain thromboxane $\mathrm{A}_{2}$-mediated mechanisms, while the peptide evokes the release of noradrenaline from sympathetic nerves by brain prostanoid other than thromboxane $\mathrm{A}_{2}$-mediated mechanisms in rats.

Key words: cyclooxygenase, glucagon-like peptide-1, plasma catecholamine, sympatho-adrenomedullary system, thromboxane $\mathrm{A}_{2}$. 


\section{INTRODUCTION}

Glucagon-like peptide-1 (GLP-1) was reported originally to be a peptide hormone released from the enteroendocrine $\mathrm{L}$ cells in the intestine to stimulate insulin secretion from the pancreas. ${ }^{1-3}$ GLP-1 is also a brain neuropeptide synthesized in the caudal regions of the nucleus of the solitary tract. ${ }^{4,5}$ Although the sites of GLP-1 synthesis in the brain are quite limited, GLP-1-immunoreactive nerve fibers and GLP-1 receptors are widespread throughout the brain. ${ }^{6}$ It has been shown that intravenous and intracerebroventricular administration of GLP-1 receptor agonists increases blood pressure and heart rate and induces c-Fos-like immunoreactivity in autonomic regulatory neurons in the brain. ${ }^{7-9}$ These observations suggest a role for GLP-1 in the regulation of several autonomic responses in the brain. ${ }^{10}$ However, the central mechanisms underlying these actions of GLP-1 remain largely undefined.

Previously, we reported that intracerebroventricular pretreatment with indomethacin, an inhibitor of cyclooxygenase, effectively reduced the increase of plasma noradrenaline and adrenaline induced by intracerebroventricularly (i.c.v.)-administered corticotrophin-releasing factor (CRF), ${ }^{11}$ arginine-vasopressin, ${ }^{12}$ and bombesin. ${ }^{13,14}$ These results suggest the involvement of brain prostanoids in the central activation of the sympatho-adrenomedullary outflow in rats. In the present study, therefore, we investigated the mechanisms involved in i.c.v.-administered GLP-1-induced elevation of plasma catecholamines with regard to the brain prostanoids in urethane-anesthetized rats. 


\section{METHODS}

\section{Experimental procedures}

Male Wistar rats weighing approximately $350 \mathrm{~g}$ were maintained in an air-conditioned room at $22-24^{\circ} \mathrm{C}$ under a constant day-night rhythm for more than 2 weeks and given food (laboratory chow, CE-2; Clea Japan, Hamamatsu, Japan) and water ad libitum. With the rats under urethane anesthesia $(1.0 \mathrm{~g} / \mathrm{kg}$, i.p.), the femoral vein was cannulated for infusion of saline $(1.2 \mathrm{~mL} / \mathrm{h})$, and the femoral artery was cannulated for collecting blood samples, as described previously. ${ }^{15}$ For some animals, acute bilateral adrenalectomy (plus hydrocortisone $5 \mathrm{mg} / \mathrm{kg}$, i.m.) or a sham operation (plus $200 \mu \mathrm{L}$ saline/animal, i.m. ${ }^{16}$ was carried out just before the experiments through bilateral dorsal incisions using an aseptic surgical technique.

Next, the animal was placed in a stereotaxic apparatus, as described previously. ${ }^{14} \mathrm{~A}$ hole was drilled in the skull for intracerebroventricular administration of test substances through a stainless-steel cannula ( $0.3 \mathrm{~mm}$ outer diameter). The stereotaxic coordinates of the tip of the cannula were as follows (in mm): AP, - $0.8 ; \mathrm{L}, 1.5 ; \mathrm{V} ; 4.0$ (AP, anterior from the bregma; L, lateral from the midline; V, below the surface of the brain), according to the rat brain atlas of Paxinos and Watson. ${ }^{17}$ Three hours were allowed to elapse before the application of GLP-1 or other reagents.

GLP-1 and other reagents (except for baicalein) were dissolved in sterile saline and injected slowly into the right cerebral ventricle in a volume of $5 \mu \mathrm{L}$ with a $10-\mu \mathrm{L}$ Hamilton syringe. In the case of baicalein, the reagent was dissolved in $N, N$-dimethyl formamide (DMF) and injected slowly into the right cerebral ventricle in a volume of 2.5 $\mu \mathrm{L}$ with a $10-\mu \mathrm{L}$ Hamilton syringe. Exendin (5-39) (a GLP-1 receptor antagonist) and (+) S-145 (a thromboxane $\mathrm{A}_{2}$ receptor antagonist) were administered i.c.v. 15 min before GLP-1 administration. Water-soluble indomethacin-Na (a cyclooxygenase inhibitor), baicalein (a lipoxygenase inhibitor) and furegrelate (a thromboxane $\mathrm{A}_{2}$ synthase inhibitor) were administered i.c.v. $30 \mathrm{~min}$ before GLP-1 administration.

All experiments were conducted in compliance with the guiding principles for the care and use of laboratory animals approved by Kochi University. 


\section{Measurement of plasma catecholamines}

Blood samples $(250 \mu \mathrm{L})$ were collected through an arterial catheter and preserved on ice during the experiments. Plasma was prepared immediately after the final sampling. Catecholamines in the plasma were extracted by the method of Anton and Sayre, ${ }^{18}$ with a slight modification, and were assayed electrochemically with high-performance liquid chromatography (HPLC). ${ }^{15}$ Briefly, after centrifugation, plasma $(100 \mu \mathrm{L})$ was transferred to a sample tube containing $30 \mathrm{mg}$ of activated alumina, $1 \mathrm{ng}$ of 3,4-dihydroxybenzylamine as an internal standard, and $3 \mathrm{~mL}$ of $0.5 \mathrm{M}$ Tris buffer $(\mathrm{pH}$ 8.6) containing 0.1 M disodium EDTA. The tube was shaken for $10 \mathrm{~min}$, and the alumina was washed three times with $4 \mathrm{~mL}$ of ice-cold, double-deionized water. Then, the catecholamines adsorbed onto the alumina were eluted with $300 \mu \mathrm{L}$ of $4 \%$ acetic acid containing $0.1 \mathrm{mM}$ disodium EDTA.

A pump (EP-300: Eicom, Kyoto, Japan), a sample injector (Model-231XL; Gilson, Villiers-le-Bel, France), and an electrochemical detector (ECD-300: Eicom) equipped with a graphite electrode were used with HPLC. Analytical conditions were as follows: detector $+450 \mathrm{mV}$ potential against an $\mathrm{Ag} / \mathrm{AgCl}$ reference electrode; column, Eicompack CA-50DS, 2.1 x $150 \mathrm{~mm}$ (Eicom); mobile phase, $0.1 \mathrm{M} \mathrm{NaH}_{2} \mathrm{PO}_{4}-\mathrm{Na}_{2} \mathrm{HPO}_{4}$ buffer (pH 6.0) containing $50 \mathrm{mg} / \mathrm{L}$ disodium EDTA, $750 \mathrm{mg} / \mathrm{L}$ 1-octane sulfate sodium (Nacalai Tesque, Kyoto, Japan) and $15 \%$ methanol, at a flow rate of $0.18 \mathrm{~mL} / \mathrm{min}$. The amount of catecholamines in each sample was calculated using the peak height ratio relative to that of 3,4-dihydroxybenzylamine. This assay could determine $0.5 \mathrm{pg}$ of noradrenaline and adrenaline accurately.

\section{Treatment of data and statistics}

Results are expressed as the mean \pm S.E.M. of the net change above the respective basal values. The data were analyzed by repeated-measure analysis of variance (ANOVA), followed by post-hoc analysis with the Bonferroni method for comparing a control to all other means (Figs. 1, 2 and 4B). When only two means were compared, the data were 
analyzed with an unpaired Student's t-test (Figs. 3, 4A and 5). $P$ values less than 0.05 were taken to indicate statistical significance.

\section{Compounds}

GLP-1 (7-36 amide) and exendin (5-39) were purchased from Peptide Institute (Osaka, Japan). Baicalein and furegrelate sodium were obtained from Biomol Research Labs (Plymouth Meeting, PA, USA). Water-soluble indomethacin sodium trihydrate and (+) S-145 were kind gifts from Merck (Rahway, NJ, USA) and Shionogi Pharmaceutical Co. Ltd. (Osaka, Japan), respectively. All other reagents were purchased from Nacalai Tesque (Kyoto, Japan). 


\section{RESULTS}

\section{Effect of GLP-1 on the plasma levels of catecholamines}

Administration of vehicle ( $5 \mu \mathrm{L}$ of saline/animal) and blood sampling five times over a 60-min period had no effect on the basal plasma levels of either noradrenaline or adrenaline (Fig. 1).

GLP-1 dose-dependently elevated plasma levels of noradrenaline and adrenaline (Fig. 1). The noradrenaline response to GLP-1 (0.3 and $1.0 \mathrm{nmol} / \mathrm{animal})$ reached a maximum at 20-30 min after administration of the peptide, and then gradually declined to near basal levels, while the response to GLP-1 (3.0 nmol/animal) reached a maximum at 20 min after administration of the peptide, and elevated levels were maintained throughout the experiments. The plasma adrenaline response to GLP-1 $(0.3,1.0$ and 3.0 $\mathrm{nmol} / \mathrm{animal}$ ) reached a maximum at $20 \mathrm{~min}$ after administration of the peptide, and then gradually declined to near basal levels (Fig. 1).

\section{Effect of exendin (5-39) on the GLP-1-induced elevation of plasma catecholamines}

Pretreatment with exendin (5-39) (a GLP-1 receptor antagonist) (10 nmol/animal) had no effect on the basal plasma levels of noradrenaline and adrenaline (Fig. 2).

Pretreatment with vehicle ( $5 \mu \mathrm{L}$ of saline/animal) slightly, but not significantly, potentiated the effect of GLP-1 (1.0 nmol/animal) on the plasma level of noradrenaline (Fig. 2). The GLP-1-induced elevation of plasma catecholamines was attenuated by pretreatment with exendin (5-39) in a dose-dependent manner (5 and $10 \mathrm{nmol} / \mathrm{animal})$ (Fig. 2).

\section{Effects of indomethacin and baicalein on the GLP-1-induced elevation of plasma catecholamines}


Pretreatment with indomethacin (a cyclooxygenase inhibitor) $(1.2 \mu \mathrm{mol}[500 \mu \mathrm{g}] /$ animal) or baicalein (a lipoxygenase inhibitor) $(1.2 \mu \mathrm{mol}[400 \mu \mathrm{g}] / \mathrm{animal}) \mathrm{had}$ no effect on the basal plasma levels of noradrenaline and adrenaline, respectively (Fig. 3, A and B).

Pretreatment with indomethacin $(1.2 \mu \mathrm{mol} / \mathrm{animal})$ effectively reduced the elevation of both catecholamines induced by GLP-1 (1.0 nmol/animal) (Fig. 3A). In contrast, pretreatment with baicalein $(1.2 \mu \mathrm{mol} / \mathrm{animal})$ slightly, but not significantly, elevated the GLP-1-induced responses (Fig. 3B).

\section{Effects of furegrelate and (+) S-145 on the GLP-1-induced elevation of plasma catecholamines}

Pretreatment with furegrelate (a thromboxane $\mathrm{A}_{2}$ synthase inhibitor) (1.8 $\mu \mathrm{mol}$ [500 $\mu \mathrm{g}] /$ animal) had no effect on the basal plasma levels of noradrenaline and adrenaline (Fig. 4A). Pretreatment with furegrelate significantly reduced the elevation of adrenaline induced by GLP-1 (1.0 nmol/animal), but the reagent had no effect on the elevation of noradrenaline induced by this peptide (Fig. 4A).

According to our previous report, ${ }^{14}$ we used (+) S-145 (a thromboxane $\mathrm{A}_{2}$ receptor antagonist) at doses of 250 and $625 \mathrm{nmol} /$ animal in the present experiment (Fig. 4B). Pretreatment with this reagent $(625 \mathrm{nmol} / \mathrm{animal})$ had no effect on the basal plasma levels of noradrenaline and adrenaline. Pretreatment with this reagent effectively attenuated the GLP-1 (1.0 nmol/animal)-induced elevation of adrenaline in a dose-dependent manner (250 and $625 \mathrm{nmol} / \mathrm{animal}$ ), while it slightly, but not significantly, reduced the elevation of noradrenaline induced by this peptide (Fig. 4B).

\section{Effect of bilateral adrenalectomy on the GLP-1-induced elevation of plasma catecholamines}

The basal plasma levels of noradrenaline and adrenaline were reduced slightly by sham operation. The basal plasma level of noradrenaline was reduced slightly, but not significantly, by bilateral adrenalectomy, while the basal plasma level of adrenaline was reduced significantly by the procedure (Fig. 5). 
The GLP-1 (1.0 nmol/animal)-induced elevation of plasma adrenaline was abolished by bilateral adrenalectomy, while the procedure had no effect on the peptide-induced elevation of plasma noradrenaline (Fig. 5). 


\section{DISCUSSION}

In the present experiment, centrally administered GLP-1 effectively elevated plasma levels of catecholamines (adrenaline $>$ noradrenaline), and these elevations were suppressed dose-dependently by exendin (5-39), a GLP-1 receptor antagonist. ${ }^{19}$ Several lines of evidence indicate that centrally administered GLP-1 induces a dose-dependent increase in blood pressure and heart rate. ${ }^{9,20,21}$ Furthermore, it has been shown that an activation of the GLP-1 receptors in the rat brain induces c-Fos expression in neurons involved in autonomic control sites, including the hypothalamic paraventricular nucleus and medullary neurons providing output to sympathetic preganglionic neurons. ${ }^{9}$ Taken together, it would be reasonable to assume that centrally administered GLP-1 elevates plasma catecholamines via an activation of brain GLP-1 receptors in rats.

Previously, we reported that the brain cyclooxygenase is involved in centrally administered CRF-, arginine-vasopressin-, and bombesin-induced elevations of plasma noradrenaline and adrenaline using indomethacin in rats. ${ }^{11,12,13}$ The elevation of plasma noradrenaline induced by centrally administered interleukin- $1 \beta$ was also attenuated by central pretreatment with indomethacin. ${ }^{22}$ Since indomethacin is a potent inhibitor of the prostaglandin-forming cyclooxygenase, ${ }^{23}$ active products of cyclooxygenase seem to be involved in the elevations of plasma catecholamines induced by these peptides in rats. However, it remains possible that active products of the brain lipoxygenases are involved in the elevations of plasma catecholamines induced by these peptides.

In the next experiment, therefore, we examined the effects of centrally administered indomethacin and baicalein, a lipoxygenase inhibitor, ${ }^{24}$ on the GLP-1-induced elevation of plasma catecholamines. These reagents were directly administered into the lateral ventricle of the rat brain. The elevation of plasma catecholamines induced by GLP-1 was abolished by central pretreatment with indomethacin $(1.2 \mu \mathrm{mol} / \mathrm{animal})$. In contrast, the same dose of baicalein had no attenuating effect on the GLP-1-induced elevation of plasma catecholamines. Collectively, it would be reasonable to assume that the active products of cyclooxygenase seem to be involved in the GLP-1-induced elevation of plasma catecholamines in rats.

We have already reported that furegrelate, a selective thromboxane $\mathrm{A}_{2}$ synthase inhibitor, ${ }^{25}$ abolished the elevation of plasma adrenaline induced by centrally administered CRF, arginine-vasopressin, or bombesin. ${ }^{11,12,14}$ Furthermore, injection of a 
thromboxane $\mathrm{A}_{2}$ mimetic into the hypothalamic paraventricular nucleus predominantly elevates plasma adrenaline. ${ }^{26}$ These results suggest the involvement of brain thromboxane $A_{2}$ in the elevation of plasma adrenaline induced by these peptides. Then, we examined the effect of furegrelate on the GLP-1-induced elevation of plasma catecholamines. The GLP-1-induced elevation of plasma adrenaline was reduced by centrally administered furegrelate, while the reagent was without effect on the GLP-1-induced elevation of plasma noradrenaline. Furthermore, (+) S-145, a thromboxane $\mathrm{A}_{2}$ receptor antagonist, ${ }^{14}$ also attenuated the GLP-1-induced elevation of plasma adrenaline, but not that of noradrenaline. Based on these results, it would be reasonable to assume that the brain thromboxane $A_{2}$ is involved in the GLP-1-induced elevation of plasma adrenaline.

In general, plasma noradrenaline reflects the activity of the sympathetic nervous system, while plasma adrenaline reflects the activity of the adrenomedullary system. Recently, we demonstrated that centrally administered arginine-vasopressin, bombesin and histamine elicit adrenal secretion of both noradrenaline and adrenaline by brain thromboxane $\mathrm{A}_{2}$-mediated mechamisms, while centrally administered CRF elicits sympathetic noradrenaline release and adrenal adrenaline secretion by brain prostaglandin $\mathrm{E}_{2}$ - and thromboxane $\mathrm{A}_{2}$-mediated mechanisms, respectively, in rats. ${ }^{14-16}$ Furthermore, it has been reported that noradrenaline-containing cells and adrenaline-containing cells in the adrenal medulla are innervated separately by preganglionic neurons in the spinal cord. ${ }^{27}$ More recently, using c-Fos expression, we demonstrated that adrenaline- and noradrenaline-containing cells in the adrenal medulla and celiac sympathetic ganglia are differentially controlled by brain thromboxane $\mathrm{A}_{2}$ and prostanoids other than thromboxane $\mathrm{A}_{2}$ (probably prostaglandin $\mathrm{E}_{2}$ ), respectively, in rats. ${ }^{28}$ In the last experiment, we performed acute bilateral adrenalectomy to determine the origin of plasma catecholamines induced by centrally administered GLP-1. Bilateral adrenalectomy abolished the centrally administered GLP-1-induced elevation of plasma adrenaline, while the procedure had no effect on the elevation of plasma noradrenaline. These results suggest that centrally administered GLP-1 evokes noradrenaline release from sympathetic nerves and adrenaline secretion from the adrenal gland in rats. GLP-1-containing nerve terminals densely innervate neurons in the hypothalamic paraventricular nucleus, ${ }^{29}$ which has been recognized as a regulatory center of the sympatho-adrenomedullary system. ${ }^{30}$ These observations further support the present 
results that central GLP-1-containing neurons regulate central sympatho-adrenomedullary outflow in rats.

In summary, we demonstrated here that centrally administered GLP-1 evokes adrenal adrenaline secretion by brain thromboxane $\mathrm{A}_{2}$-mediated mechanisms and sympathetic noradrenaline release by mechanisms involving prostaglandins other than thromboxane $\mathrm{A}_{2}$ (probably prostaglandin $\mathrm{E}_{2}$ ) in rats. 


\section{ACKNOWLEDGMENT}

This work was supported in part by a grant from the Smoking Research Foundation of Japan. 


\section{REFERENCES}

1. Mojsov S, Heinrich G, Wilson IB, Ravazzola M, Orci L, Habener JF.

Preproglucagon gene expression in pancreas and intestine diversifies at the level of post-translational processing. J. Biol. Chem. 1986; 261: 11880-9.

2. Mojsov S, Weir GC, Habener JF. Insulinotropin: glucagon-like peptide 1 (7-37) coencoded in the glucagon gene is a potent stimulator of insulin release in the perfused rat pancreas. J. Clin. Invest. 1987; 79: 616-9.

3. Kreymann B, Williams G, Ghatei MA, Bloom SR. Glucagon-like peptide-1 7-36: a physiological incretin in man. Lancet 1987; 2: 1300-4.

4. Jin SL, Han VK, Simmons JG, Towle AC, Lauder JM, Lund PK. Distribution of glucagon-like peptide-I (GLP-I), glucagon, and glicentin in the rat brain: an immunocytochemical study. J. Comp. Neurol. 1988; 271: 519-32.

5. Larsen PJ, Tang-Christensen M, Holst JJ, Orskov C. Distribution of glucagon-like peptide-1 and other preproglucagon-derived peptides in the rat hypothalamus and brainstem. Neuroscience 1997; 77: 257-70.

6. Merchenthaler I, Lane M, Shughrue P. Distribution of pre-pro-glucagon and glucagon-like peptide-1 receptor messenger RNAs in the rat central nervous system. J. Comp. Neurol. 1999; 403: 261-80.

7. Barragan JM, Eng J, Rodriguez R, Blazquez E. Neural contribution to the effect of glucagon-like peptide-1-(7-36) amide on arterial blood pressure in rats. Am. J. Physiol. 1999; 277: E784-E91.

8. Seeley RJ, Blake K, Rushing PA, et al. The role of CNS glucagon-like peptide-1 (7-36) amide receptors in mediating the visceral illness effects of lithium chloride. $J$. Neurosci. 2000; 20: 1616-21.

9. Yamamoto H, Lee CE, Marcus JN, et al. Glucagon-like peptide-1 receptor stimulation increases blood pressure and heart rate and activates autonomic regulatory neurons. J. Clin. Invest. 2002; 110: 43-52.

10. Turton MD, O'Shea D, Gunn I, et al. A role for glucagon-like peptide-1 in the central regulation of feeding. Nature 1996; 379: 69-72. 
11. Yokotani K, Murakami Y, Okada S, Hirata M. Role of brain arachidonic acid cascade on central $\mathrm{CRF}_{1}$ receptor-mediated activation of sympatho-adrenomedullary outflow in rats. Eur. J. Pharmacol. 2001; 419: 183-9.

12. Okada S, Murakami Y, Nakamura K, Yokotani K. Vasopressin $\mathrm{V}_{1}$ receptor-mediated activation of central sympatho-adrenomedullary outflow in rats. Eur. J. Pharmacol. 2002; 457: 29-35.

13. Okuma Y, Yokotani K, Osumi Y. Brain prostaglandins mediate the bombesin-induced increase in plasma levels of catecholamines. Life Sci. 1996; 59: 1217-25.

14. Yokotani K, Okada S, Nakamura K, et al. Brain prostanoid TP receptor-mediated adrenal noradrenaline secretion and $\mathrm{EP}_{3}$ receptor-mediated sympathetic noradrenaline release in rats. Eur. J. Pharmacol. 2005; 512: 29-35.

15. Okada S, Murakami Y, Yokotani K. Role of brain thromboxane $A_{2}$ in the release of noradrenaline and adrenaline from adrenal medulla in rats. Eur. J. Pharmacol. 2003; 467: 125-31.

16. Shimizu T, Okada S, Yamaguchi N, Sasaki T, Lu L, Yokotani K. Centrally administered histamine evokes the adrenal secretion of noradrenaline and adrenaline by brain cyclooxygenase-1- and thromboxane $\mathrm{A}_{2}$-mediated mechanisms in rats. Eur. J. Pharmacol. 2006; 541: 152-7.

17. Paxinos G, Watson C (eEds.). The Rat Brain in Stereotaxic Coordinates, 3rd edn. Academic Press, New York. 1997.

18. Anton AH, Sayre DF. A study of the factors affecting the aluminum oxide-trihydroxyindole procedure for the analysis of catecholamines. J. Pharmacol. Exp. Ther. 1962; 138: 360-75.

19. Montrose-Rafizadeh C, Yang H, Rodgers BD, Beday A, Pritchette LA, Eng J. High potency antagonists of the pancreatic glucagon-like peptide-1 receptor. J. Biol. Chem. 1997; 272: 21201-6.

20. Bojanowska E, Stempniak B. Effects of centrally or systemically injected glucagon-like peptide-1 (7-36) amide on release of neurohypophysial hormones and blood pressure in the rat. Regul. Pept. 2000; 91: 75-81.

21. Isbil-Buyukcoskun N, Gulec G. Effects of intracerebroventricularly injected glucagon-like peptide-1 on cardiovascular parameters; role of central cholinergic system and vasopressin. Regul. Pept. 2004; 118: 33-8. 
22. Murakami Y, Yokotani K, Okuma Y, Osumi Y. Nitric oxide mediates central activation of sympathetic outflow induced by interleukin-1 beta in rats. Eur. J. Pharmacol. 1996; 317: 61-6.

23. Insel PA. Analgesic-antipyretic and antiinflammatory agentsand drugs employed in the treatment of gout. In: Hardman JG, Limbird LE, Molinoff PB, Ruddon RW, Gilman AG (eds.). Goodman and Gilman's The Pharmacological Basis of Therapeutics. McGraw-Hill, New York, NY, 1996; 617-58.

24. Sekiya K, Okuda H. Selective inhibition of platelet lipoxygenase by baicalein. Biochem. Biophys. Res. Commun. 1982; 105: 1090-5.

25. Gorman RR, Johnson RA, Spilman CH, Aiken JW. Inhibition of platelet thromboxane $\mathrm{A}_{2}$ synthase activity by sodium 5-(3'-pyridinylmethyl)benzofuran-2-carboxylate. Prostaglandins 1983; 26: $325-42$.

26. Murakami Y, Okada S, Nishihara M, Yokotani K. Roles of brain prostaglandin $\mathrm{E}_{2}$ and thromboxane $\mathrm{A}_{2}$ in the activation of the central sympatho-adrenomedullary outflow in rats. Eur. J. Pharmacol. 2002; 452: 289-94.

27. Edwards SL, Anderson CR, Southwell BR, McAllen RM. Distinct preganglionic neurons innervate noradrenaline and adrenaline cells in the cat adrenal medulla. Neuroscience 1996; 70: 825-32.

28. Yamaguchi-Shima N, Okada S, Shimizu T, et al. Adrenal adrenaline- and noradrenaline-containing cells and celiac sympathetic ganglia are differentially controlled by centrally administered corticotropin-releasing factor and arginine-vasopressin in rats. Eur. J. Pharmacol. 2007; 564: 94-102.

29. Sarkar S, Fekete C, Legradi G, Lechan RM. Glucagon like peptide-1 (7-36) amide (GLP-1) nerve terminals densely innervate corticotropin-releasing hormone neurons in the hypothalamic paraventricular nucleus. Brain Res. 2003; 985: 163-8.

30. Sawchenko PE, Swanson LW. The organization of forebrain afferents to the paraventricular and supraoptic nuclei of the rat. J. Comp. Neurol. 1983; 218: 121-44. 


\section{FIGURE LEGENDS}

Fig. 1 Effect of GLP-1 on plasma catecholamine levels. Arrow indicates the administration of GLP-1 (0.3, 1.0 and $3.0 \mathrm{nmol} /$ animal, i.c.v.) or vehicle (5 $\mu \mathrm{L}$ saline/animal, i.c.v.). $\bigcirc$, vehicle $(n=4) ; \boldsymbol{\Delta}, 0.3 \mathrm{nmol}(n=9) ; \bullet, 1.0 \mathrm{nmol}(n=10)$; $3.0 \mathrm{nmol}(n=5)$. $*$ Significantly different $(P<0.05)$ from vehicle $(5 \mu \mathrm{L}$ saline $)$-treated control with Bonferoni method. Each point represents the mean \pm S.E.M. The actual values for noradrenaline and adrenaline at 0 min were $400 \pm 46$ and $322 \pm 45 \mathrm{pg} / \mathrm{mL}(n=$ 28), respectively.

Fig. 2 Effect of exendin (5-39) (a GLP-1 receptor antagonist) on the GLP-1-induced elevation of plasma catecholamines. Exendin (5-39) (5 and $10 \mathrm{nmol} / \mathrm{animal}$, i.c.v.) or vehicle-1 (5 $\mu \mathrm{L}$ saline/animal, i.c.v.) was administered 15 min before GLP-1 (1.0 nmol/animal, i.c.v.) or vehicle-2 (5 $\mu \mathrm{L}$ saline/animal, i.c.v.). $\bigcirc$, vehicle-1 plus vehicle-2 $(n=4)$; $\square$, exendin (5-39) (10 nmol/animal) plus vehicle-2 $(n=4)$; GLP-1 $(n=16) ; \boldsymbol{\Delta}$, exendin (5-39) (5 nmol/animal) plus GLP-1 $(n=5) ; \boldsymbol{a}$, exendin (5-39) (10 nmol/animal) plus GLP-1 $(n=6)$. *Significantly different $(P<0.05)$ from vehicle-1 (5 $\mu \mathrm{L}$ saline)- and GLP-1-treated group with Bonferoni method. Other conditions were the same as those in Fig. 1. The actual values for noradrenaline and adrenaline at $0 \mathrm{~min}$ were $376 \pm 56$ and $263 \pm 56 \mathrm{pg} / \mathrm{mL}$ in the vehicle- $1(5 \mu \mathrm{L}$ saline)-pretreated group $(n=20), 580 \pm 68$ and $376 \pm 83 \mathrm{pg} / \mathrm{mL}$ in the exendin (5-39) (5 nmol)-pretreated group ( $n=5), 204 \pm 23$ and $180 \pm 54 \mathrm{pg} / \mathrm{mL}$ in the exendin (5-39) (10 nmol)-pretreated group $(n=10)$, respectively.

Fig. 3 Effects of indomethacin (a cyclooxygenase inhibitor) and baicalein (a lipoxygenase inhibitor) on the GLP-1-induced elevation of plasma catecholamines. (A) Indomethacin (1.2 $\mu \mathrm{mol} / \mathrm{animal}$, i.c.v.) or vehicle-1 (5 $\mu \mathrm{L}$ saline/animal, i.c.v.) was administered $30 \mathrm{~min}$ before GLP-1 (1.0 nmol/animal, i.c.v.) or vehicle-2 (5 $\mu \mathrm{L}$ saline/animal, i.c.v.). $\bigcirc$, vehicle-1 plus vehicle-2 $(n=4) ; \triangle$, indomethacin plus vehicle-2 $(n=4)$; $\boldsymbol{O}$, vehicle-1 plus GLP-1 $(n=12) ; \boldsymbol{\Delta}$, indomethacin plus GLP-1 $(n=7)$. (B) Baicalein (1.2 $\mu \mathrm{mol} / \mathrm{animal}$, i.c.v.) or vehicle-1 (2.5 $\mu \mathrm{L}$ DMF/animal, i.c.v.) was administered $30 \mathrm{~min}$ before GLP-1 (1.0 nmol/animal, i.c.v.) or vehicle-2 (5 $\mu \mathrm{L}$ saline/animal, i.c.v.). $\bigcirc$, vehicle-1 plus vehicle-2 $(n=3), \square$, baicalein plus vehicle-2 ( $n$ 
$=5) ; 0$, vehicle-1 plus GLP-1 $(n=6) ; \boldsymbol{\square}$, baicalein plus GLP-1 $(n=5)$ * Significantly different $(P<0.05)$ from vehicle-1 $(5 \mu \mathrm{L}$ saline/2.5 $\mu \mathrm{L}$ DMF)- and GLP-1-treated group with Student's $t$-test in (A) and (B), respectively. Other conditions were the same as those in Figs. 1 and 2. The actual values for noradrenaline and adrenaline at 0 min were $430 \pm 64$ and $224 \pm 21 \mathrm{pg} / \mathrm{mL}$ in the vehicle-1 (5 $\mu \mathrm{L}$ saline)-pretreated group ( $n=16), 457 \pm 82$ and $500 \pm 100 \mathrm{pg} / \mathrm{mL}$ in the indomethacin-pretreated group $(n=11)$ in $(\mathrm{A}) ; 354 \pm 47$ and $221 \pm 65 \mathrm{pg} / \mathrm{mL}$ in the vehicle-1 (2.5 $\mu \mathrm{L}$ DMF)-pretreated group $(n=9), 314 \pm 42$ and $341 \pm 77 \mathrm{pg} / \mathrm{mL}$ in the baicalein-pretreated group $(n=10)$ in $(\mathrm{B})$, respectively.

Fig. 4 Effects of furegrelate (a thromboxane $A_{2}$ synthase inhibitor) and (+) S-145 (a thromboxane $\mathrm{A}_{2}$ receptor antagonist) on the GLP-1-induced elevation of plasma catecholamines. (A) Furegrelate $(1.8 \mu \mathrm{mol} /$ animal, i.c.v. $)$ or vehicle-1 $(5 \mu \mathrm{L}$ saline/animal, i.c.v.) was administered $30 \mathrm{~min}$ before GLP-1 (1.0 nmol/animal, i.c.v.) or vehicle-2 (5 $\mu \mathrm{L}$ saline/animal, i.c.v.). $\bigcirc$, vehicle-1 plus vehicle-2 $(n=4)$ (cited from Fig. $3 \mathrm{~A}) ; \nabla$, furegrelate plus vehicle-2 $(n=6) ; \boldsymbol{\bullet}$, vehicle-1 plus GLP-1 $(n=12)$ (cited from Fig. 3A); $\boldsymbol{\nabla}$, furegrelate plus GLP-1 $(n=6)$. (B) (+) S-145 (250 and $625 \mathrm{nmol} / \mathrm{animal}$, i.c.v.) or vehicle-1 (5 $\mu \mathrm{L}$ saline/animal, i.c.v.) was administered 15 min before GLP-1 (1.0 nmol/animal, i.c.v.) or vehicle-2 (5 $\mu \mathrm{L}$ saline/animal, i.c.v.). $\bigcirc$, vehicle-1 plus vehicle-2 ( $n=4)$ (cited from Fig. 2); $\square$, (+) S-145 (625 nmol/animal, i.c.v.) plus vehicle-2 $(n=3)$;, vehicle-1 plus GLP-1 $(n=16)$ (cited from Fig. 2); $\boldsymbol{\Delta},(+)$ S-145 (250 nmol) plus GLP-1 ( $n=4) ; \mathbf{a},(+) \mathrm{S}-145$ (625 nmol) plus GLP-1 (n=6).

*Significantly different $(P<0.05)$ from vehicle-1 $(5 \mu \mathrm{L}$ saline)- and GLP-1-treated group with Student's $t$-test in (A) and Bonferoni method in (B), respectively. Other conditions were the same as those in Figs. 1-3. The actual values for noradrenaline and adrenaline at 0 min were $430 \pm 64$ and $224 \pm 21 \mathrm{pg} / \mathrm{mL}$ in the vehicle- 1 ( $5 \mu \mathrm{L}$ saline)-pretreated group ( $n$ $=16), 425 \pm 43$ and $319 \pm 40 \mathrm{pg} / \mathrm{mL}$ in the furegrelate-pretreated group $(n=12)$ in $(\mathrm{A})$; $376 \pm 56$ and $263 \pm 56 \mathrm{pg} / \mathrm{mL}$ in the vehicle-1 ( $5 \mu \mathrm{L}$ saline)-pretreated group $(n=20)$, $143 \pm 11$ and $155 \pm 58 \mathrm{pg} / \mathrm{mL}$ in the $(+) \mathrm{S}-145(250 \mathrm{nmol})$-pretreated group $(n=4), 251 \pm 55$ and $126 \pm 30 \mathrm{pg} / \mathrm{mL}$ in the $(+) \mathrm{S}-145(625 \mathrm{nmol})$-pretreated group $(n=9)$ in $(\mathrm{B})$, respectively.

Fig. 5 Effect of acute bilateral adrenalectomy on the GLP-1-induced elevation of catecholamines. Hydrocortisone $(5 \mathrm{mg} / \mathrm{kg})$ or saline $(200 \mu \mathrm{L} / \mathrm{animal})$ was administered 
intramuscularly in the adrenalectomized group ( $\square$ ) or sham-operated group $(\mathbf{O})$, respectively. Arrow indicates the administration of GLP-1 (1.0 nmol/animal, i.c.v.). *Significantly different $(P<0.05)$ from sham-operated group with Student's t-test. Other conditions were the same as those in Figs. 1-4. The actual values for noradrenaline and adrenaline at $0 \mathrm{~min}$ were $281 \pm 81$ and $143 \pm 36 \mathrm{pg} / \mathrm{mL}$ in the sham-operated group $(n=5)$ and $99 \pm 17$ and $52 \pm 6 \mathrm{pg} / \mathrm{mL}$ in the bilateral adrenalectomized group $(n=5)$, respectively. 


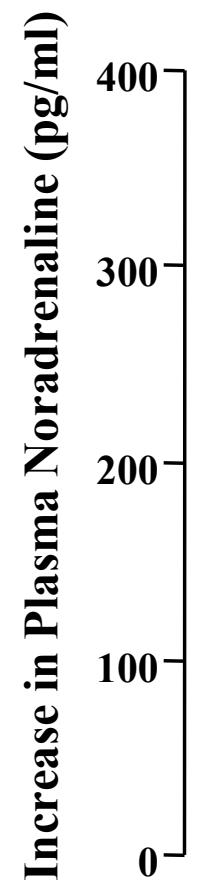

GLP-1 or Vehicle (i.c.v.)
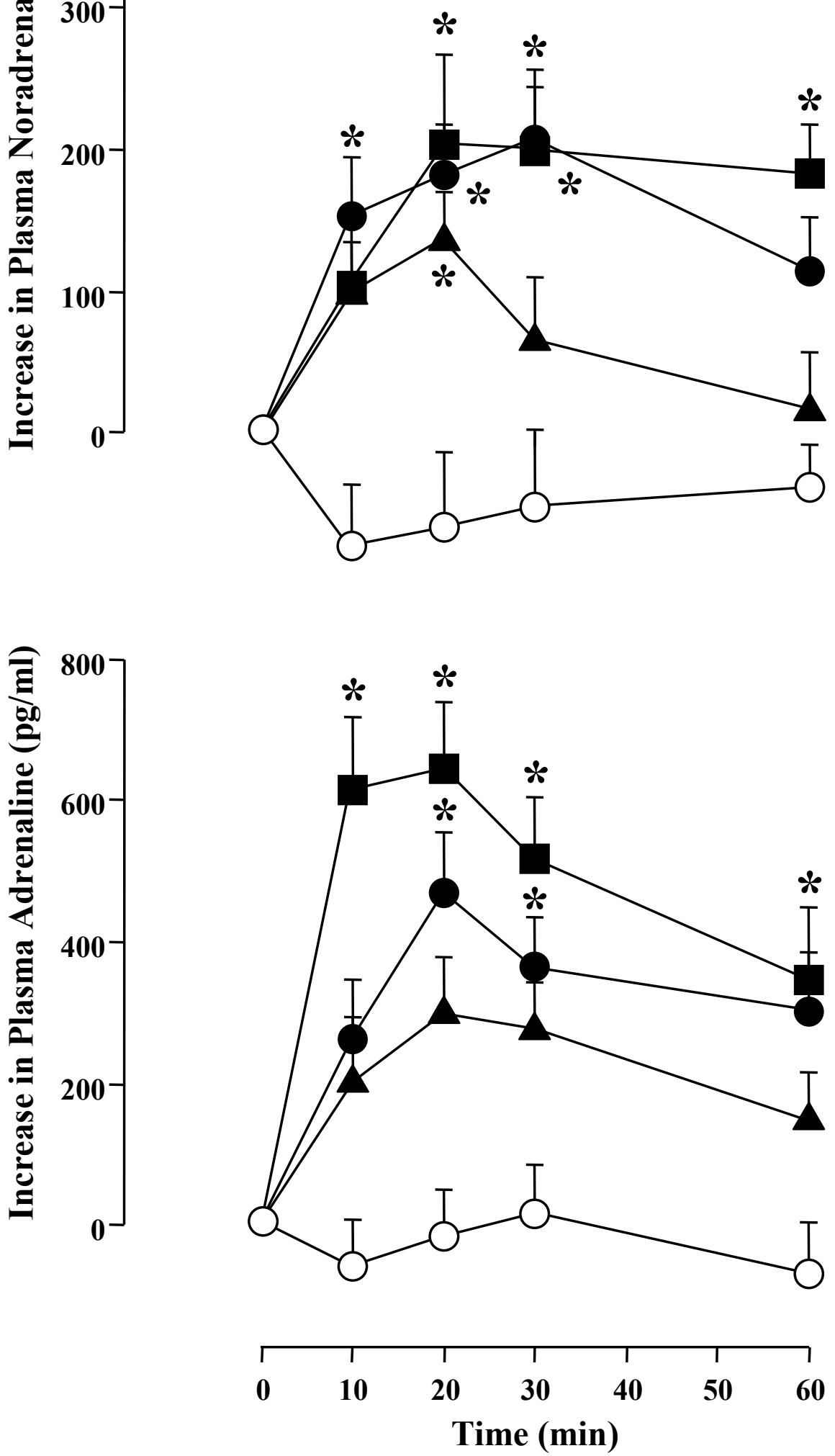


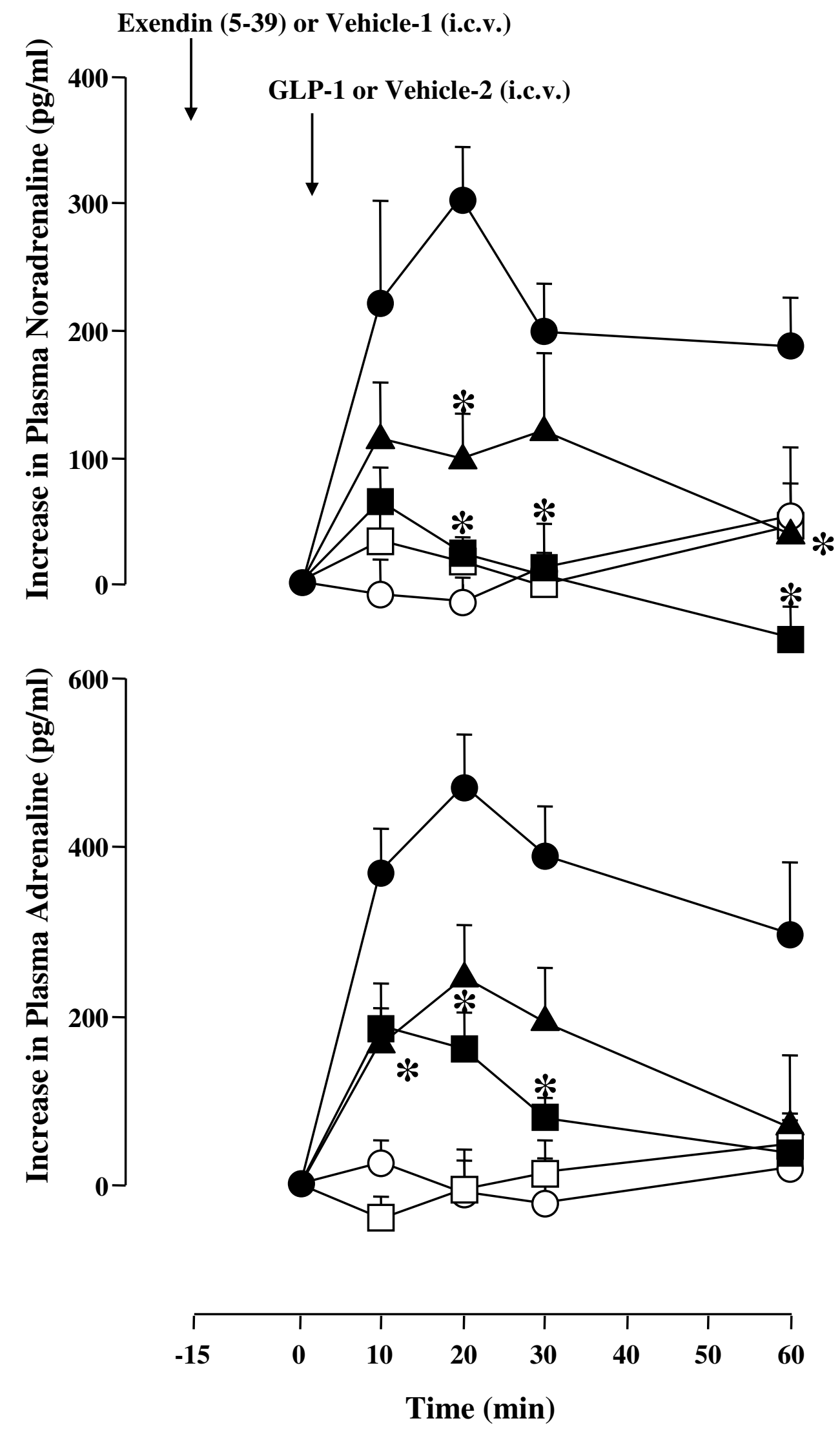


A

Indomethacin or Vehicle-1 (i.c.v.)
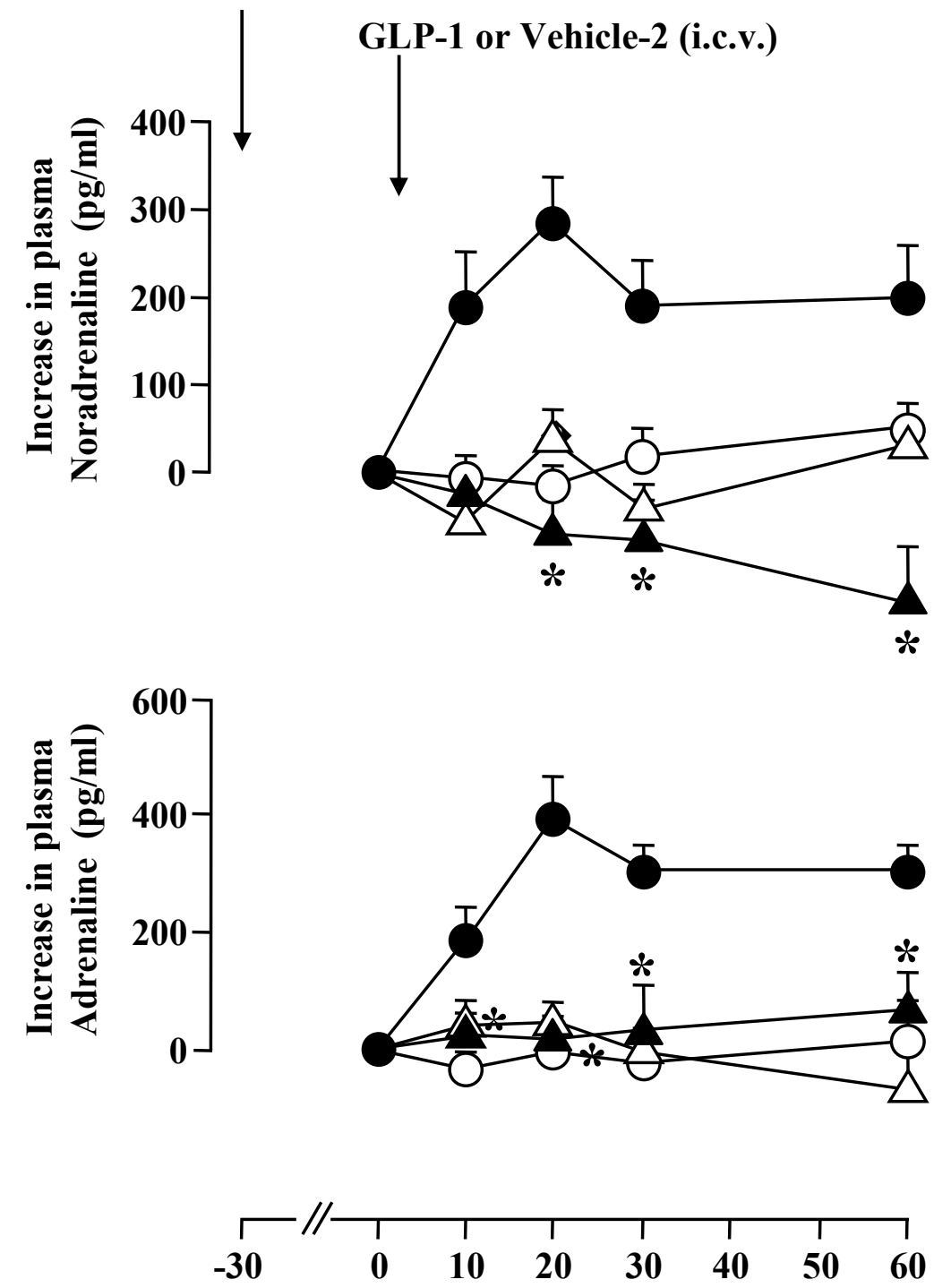

Time (min)
B

Baicalein or Vehicle-1 (i.c.v.)
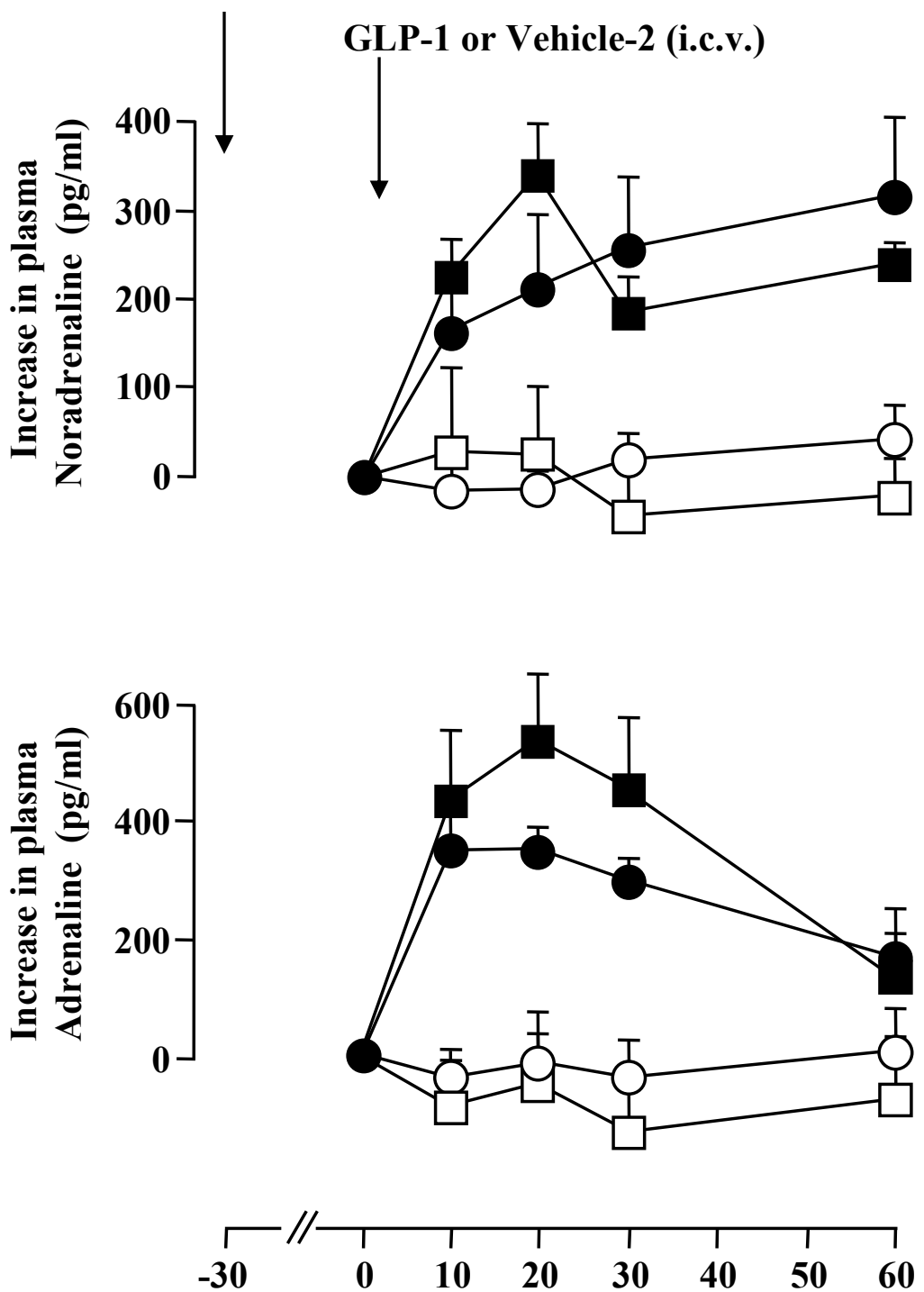

Time (min) 
A
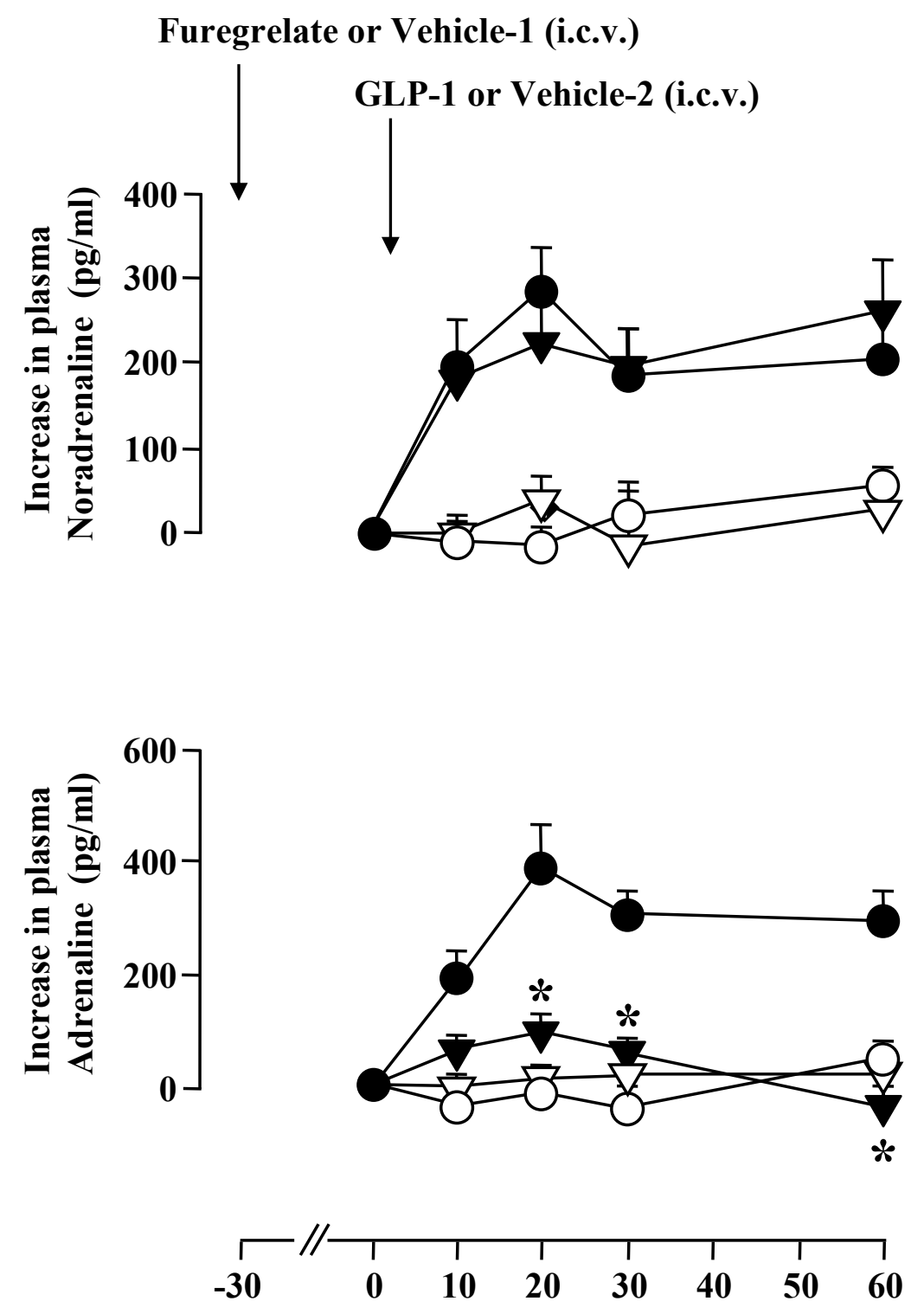

Time (min)
B

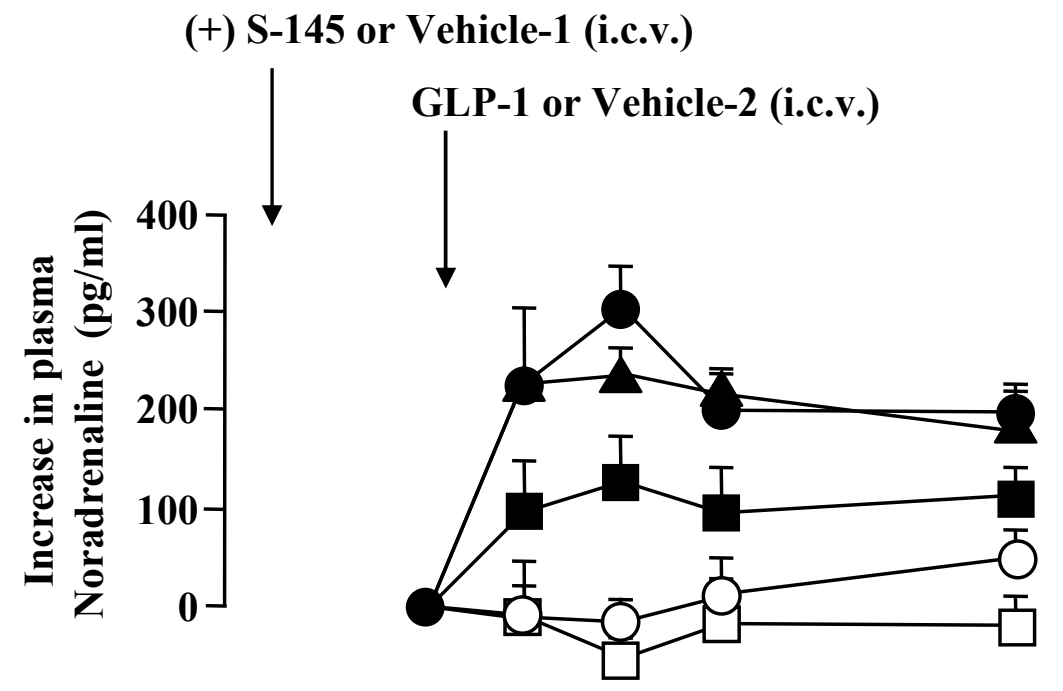

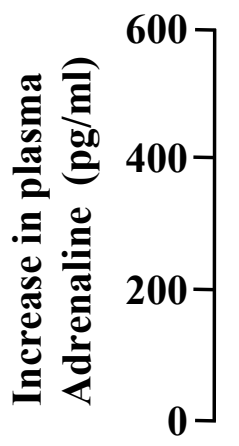

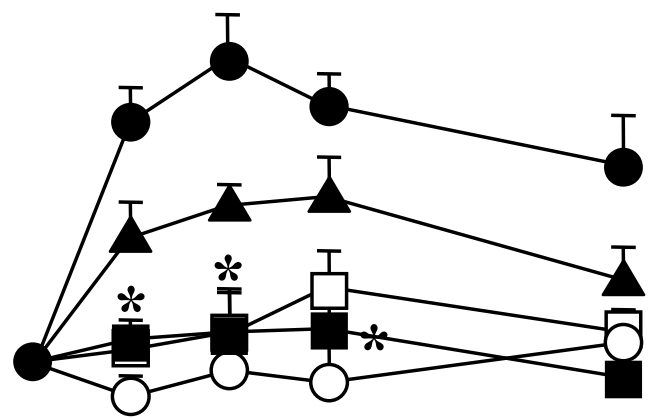

Time (min) 

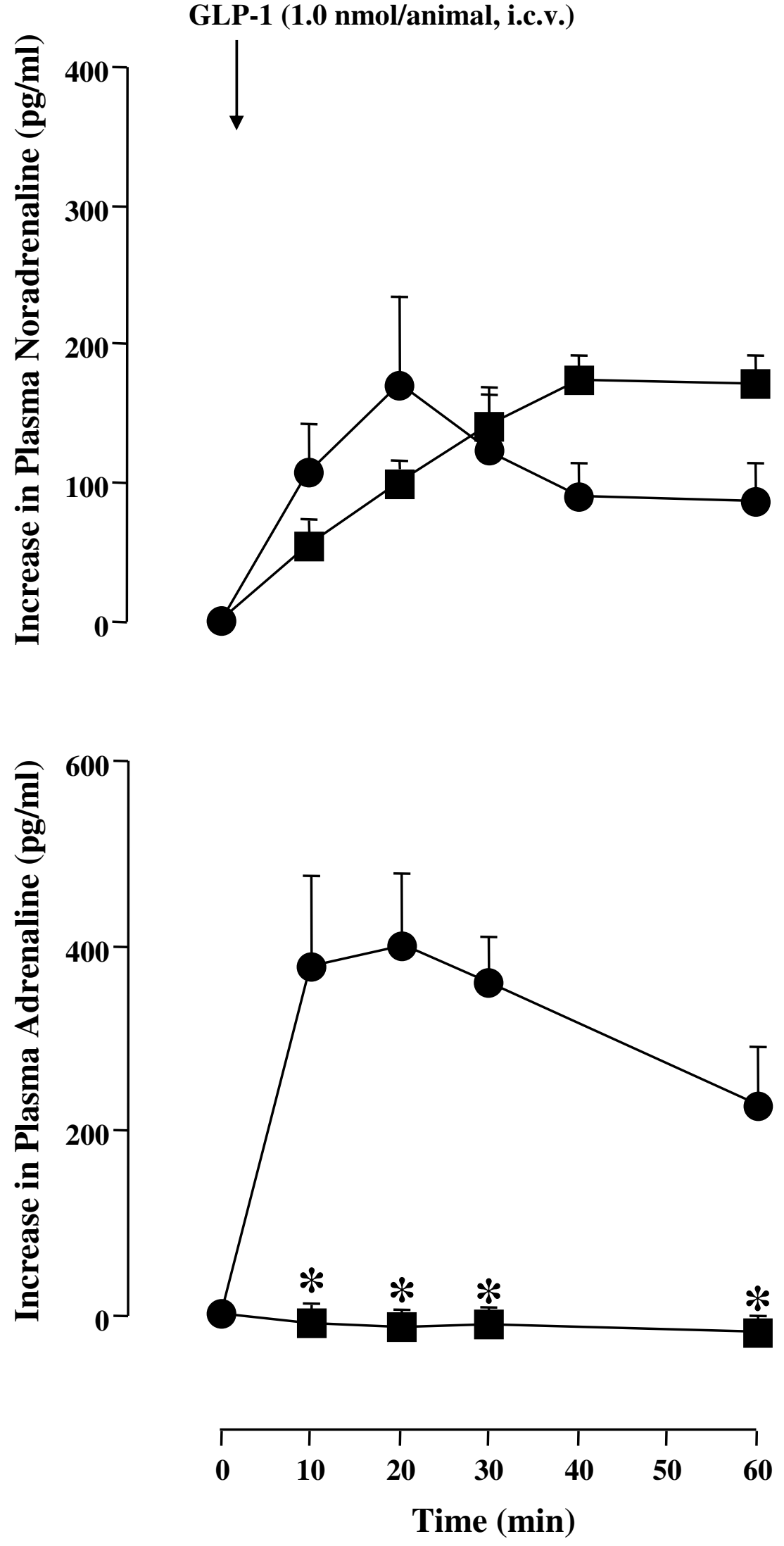